\title{
PERANAN IPTEK NUKLIR DALAM EKSPLORASI HIDROKARBON
}

\author{
EKO BUDI LELONO, ISNAWATI \\ Puslitbang Teknologi Minyak dan Gas Bumi "LEMIGAS, \\ Jl. Cileduk Raya kav. 109, Jakarta \\ Telp.021-7394662, Faksimili 021-7394662 \\ ekobl@lemigas.esdm.go.id
}

\begin{abstract}
Abstrak
PERANAN IPTEK NUKLIR DALAM EKSPLORASI HIDROKARBON. Perkembangan iptek nuklir berpengaruh terhadap teknik eksplorasi hidrokarbon, antara lain terbukti dengan adanya penggunaan isotop radioaktif untuk menentukan umur absolute batuan. Penentuan umur batuan yang pada awalnya menggunakan fosil penunjuk umur (baik mikro maupun makro-fosil) yang menghasilkan umur relatif batuan, belakangan ini diperkaya dengan metode perhitungan peluruhan mineral radioaktif untuk menentukan umur absolute batuan, sehingga posisi stratigrafi suatu lapisan batuan (batuan induk dan reservoir) dapat ditentukan dengan pasti. Sementara itu, aplikasi teknologi nuklir juga dipergunakan dalam survey sumur pemboran eksplorasi yang antara lain dikenal dengan Nuclear Magnetic Resonance (NMR) yang membantu ahli geologi dalam mengukur porositas dan permiabilitas secara langsung di lapangan, sehingga dapat memprediksi keberadaan hidrokarbon. Dari sisi sedimentologi, iptek nuklir juga diaplikasikan dalam laboratorium $X$ Ray Diffraction (XRD Laboratory) untuk menentukan jenis mineral penyusun batuan dan laboratorium Scanning Electron Microscope (SEM Laboratory) untuk mengetahui porositas batuan. Kedua hal tersebut membantu ahli eksplorasi dalam menyusun manajemen reservoir.
\end{abstract}

Kata kunci: hidrokarbon

\begin{abstract}
THE ROLE OF THE NUCLEAR SCIENCE AND TECHNOLOGY IN HYDROCARBON. The development of the nuclear science and technology influences the method of hydrocarbon exploration as shown by the use of radioactive isotope to determine the absolute age of the rock. Traditionally, the age determination relies on the occurrence of index fossil, both micro and macro forms, to define the relative age of the rock. The absolute age is basically defined based on the calculation of the decay of the selected radioactive mineral. By referring to its absolute age, the rock (source rock or reservoir) can be precisely put in the certain stratigraphic level. On the other hand, the nuclear technology - so called $\mathrm{nmr}$ (nuclear magnetic resonance) - is applied in the well exploration survey to measure the porosity and the permeability of the rock for predicting the existence of hydrocarbon. From the sedimentological view point, the nuclear technology is used in $\mathrm{x}$ ray diffraction (xrd) laboratory to identify mineral in the reservoir rock. In addition, it is also applied in scanning electron microscope (sem) laboratory for estimating the porosity of reservoir. These kinds of information are required by the explorationist to create reservoir management.
\end{abstract}

Keyword: hydrocarbon 


\section{PENDAHULUAN}

Perkembangan ilmu pengetahuan dan teknologi, khususnya teknologi nuklir banyak berpengaruh terhadap kegiatan eksplorasi hidrokarbon. Banyak metode yang terkait dengan kegiatan eksplorasi dikembangkan, sehingga analisis dan interpretasi yang dibuat lebih akurat. Beberapa metode yang menjadi standar dalam kegiatan eksplorasi antara lain Strontium Isotope Stratigraphy (SIS), Scanning Electron Microscope (SEM), X Ray Diffraction (XRD) dan logging menggunakan teknik Nuclear Magnetic Resonance (NMR). Puslibang Teknologi Minyak dan Gas Bumi "LEMIGAS", yang merupakan satu-satunya lembaga litbang di bidang migas milik pemerintah telah melengkapi sebagian laboratoriumnya dengan peralatan berbasis teknologi nuklir yang umumnya didatangkan dari negara-negara maju melalui kerja sama bilateral dengan pemerintah Indonesia. Peralatan tersebut yang dimaksudkan untuk mendukung kegiatan eksplorasi migas antara lain adalah SEM dan XRD. Agar peralatan tersebut berfungsi maksimal, maka LEMIGAS telah mengirimkan pegawainya ke luar negeri untuk berlatih mengoperasikannya. Bahkan ada pegawai yang menempuh pendidikan S-2 dan S-3 di luar negeri dengan topik yang terkait dengan penggunaan iptek nuklir dalam menunjang kegiatas eksplorasi migas. Peralatan yang terkait dengan iptek nuklir ini digunakan dalam kegiatan litbang yang dibiayai pemerintah lewat DIPA atau yang dikenal sebagai in-house research, maupun kegiatan komersial berupa pelayanan jasa teknologi (commercial work) melalui PNBP mengingat LEMIGAS adalah lembaga litbang bersifat swadana, sehingga diijinkan untuk mencari pendapatan (income) dari pihak luar (pengguna). Sejauh ini, pengalaman menunjukkan bahwa penggunaan peralatan berbasis nuklir ini memberikan nilai tambah kelitbangan sebagai hasil in-house research. Di sisi lain, penggunaan peralatan berbasis iptek nuklir meningkatkan kemampuan LEMIGAS sebagai lembaga penyedia jasa litbang (jasa teknologi) yang dapat dipercaya. Dalam bidang Lingkungan Kesehatan dan Keselamatan Kerja (LK3), Puslitbang Teknologi Migas "LEMIGAS" telah menerapkan sistem manajemen lingkungan yang tertuang dalam OHSAS 18001, yang juga mencakup pencegahan dan penanggulangan bahaya radiasi yang mungkin terjadi akibat kebocoran yang timbul dari penggunaan peralatan berbasis nuklir tersebut.

\section{Strontium Isotope Stratigraphy (SIS)}

Secara konvensional ahli geologi sering menggunakan fosil mikro untuk menyusun stratigrafi suatu daerah, yang dikenal sebagai biostratigrafi. Umur lapisan batuan yang ditentukan berdasarkan kemunculan fosil indeks tertentu bersifat relatif, artinya berkisar dari satu umur absolut sampai umur absolut lainnya (Lampiran 1). Misalnya kemunculan spesies foraminifera besar Spiroclypeus leupoldi pada suatu batuan menunjukkan bahwa batuan tersebut berumur Miosen awal yang berkisar antara 14 juta sampai 22,5 juta tahun yang lalu (Ma). Dengan demikian kisaran umurnya mencapai 8,5 juta tahun, yang berarti relatif panjang. Penerapan iptek 
berbasis nuklir dalam penentuan umur batuan memberikan umur absolut batuan tersebut, sehingga membantu ahli geologi menempatkan batuan secara pasti dalam suatu runtunan stratigrafi. Salah satu metode yang dikembangkan dari penerapan iptek nuklir ini adalah Stronsium Isotope Stratigraphy (SIS). Sayangnya peralatan yang menunjang studi SIS belum tersedia di LEMIGAS. Sehingga selama ini untuk keperluan analisis SIS, samples dikirim kepada pihak penyedia jasa yang memiliki peralatan tersebut.

Pada awalnya sebelum iptek nuklir diterapkan, penentuan umur batuan mengacu pada kemunculan mikro fosil, baik yang hidup di darat sepert foraminifera dan nanoplangton maupun di laut seperti polen dan spora (Gambar 1). Selain itu juga, ahli stratigrafi terdahulu menggunakan makro fosil untuk menentukan umur suatu batuan sedimen seperti fosil daun, buah, tulang dan lain sebagainya. Fosil-fosil tersebut secara alamiah terawetkan dalam suatu batuan sedimen yang diendapkan pada satu kurun waktu tertentu.

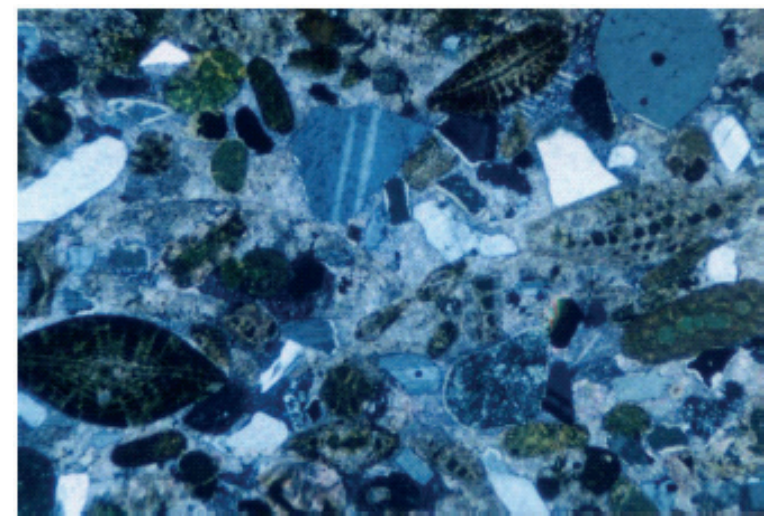

Gambar 1. Foraminifera Besar Yang Ditemukan Pada Sayatan Batuan

Fosil-fosil ini hanya ditemukan pada kisaran umur stratigrafi tertentu dan disebut sebagai fosil indeks. Lampiran 2 memperlihatkan kisaran fosil indeks foraminifera besar dalam kisaran umur geologi Tersier. Dengan demikian ditemukannya fosil indeks dalam suatu batuan sedimen dapat dijadikan dasar dalam menentukan umur batuan tersebut, tentu saja berupa kisaran umur seperti dicontohkan pada Lampiran 2. Metode ini terus dipakai dan dikembangkan sampai saat ini. Para ahli biostratigrafi berusaha menemukan fosil indeks baru yang memungkinkannya mempersempit kisaran umur batuan, sehingga mampu memisahkan lapisan batuan menjadi bagian-bagian yang lebih kecil.

Hal ini sangat diperlukan dalam pekerjaan korelasi stratigrafi lapisan batuan yang menjadi obyek penelitian seperti lapisan reservoir dan batuan induk, dari satu lokasi ke lokasi lain atau dari satu sumur ke sumur lain sehingga diketahui penyebaran lapisan tersebut secara lateral dan vertikal (Gambar 2). Informasi tentang penyebaran lapisan reservoir secara lateral dan vertikal akan 
mempengaruhi perhitungan cadangan hidrokarbon yang terdapat di suatu daerah tertentu dan menentukan strategi eksplorasi ke depan.

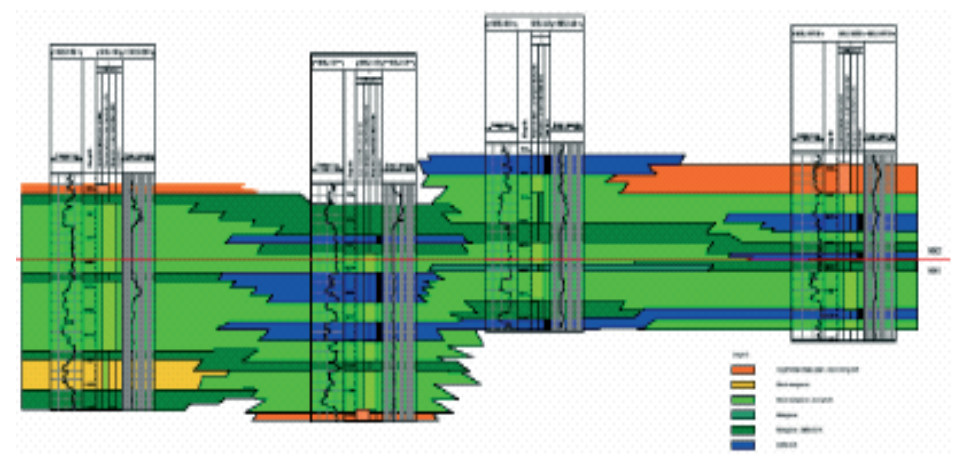

Gambar 2. Korelasi Lapisan Batuan Berdasarkan Analisis Biosatigrafi

Penerapan metode SIS menghasilkan umur batuan secara absolut, sehingga ahli stratigrafi secara tepat dapat menempatkan posisi suatu lapisan batuan dalam suatu susunan stratigrafi. Hal ini bermanfaat dalam melakukan korelasi batuan terutama reservoir dan batuan induk sehingga dapat diketahui penyebarannya secara pasti. Analisis SIS dilakukan terhadap material karbonat yang banyak mengandung unsur Stronsium. Material karbonat umumnya terdapat pada batuan sedimen yang terbentuk di lingkungan laut. Seperti diketahui Stronsium (Sr) adalah komponen larutan terbanyak ke sembilan di dalam air laut dengan konsentrasi mencapai 8 $\mathrm{mg} /$ liter. Secara geokimia elemen ini berkelakuan seperti Ca. Ketika batuan karbonat terbentuk di lingkungan laut, Sr membentuk kristal dalam batuan yang jumlah mencapai ribuan ppm. Elemen Sr yang terbentuk dalam batuan tidak mengalami pemisahan isotopik (isotopic fractionation), sehingga perbandingan ${ }^{87} \mathrm{Sr} /{ }^{86} \mathrm{Sr}$ secara langsung menggambarkan kondisi air laut pada saat itu. Perbandingan ${ }^{87} \mathrm{Sr} /{ }^{86} \mathrm{Sr}$ bersifat seragam di semua tempat di dunia. Perbandingan ${ }^{87} \mathrm{Sr} /{ }^{86} \mathrm{Sr}$ ini dapat diketahui dengan menggunakan perconto batuan karbonat. Perubahan perbandingan ${ }^{87} \mathrm{Sr} /{ }^{86} \mathrm{Sr}$ sepanjang waktu geologi berhasil diamati oleh peneliti terdahulu seperti Mc Arthur (2001), Hodell dkk (1991) dan Denison (1990). Perubahan ini digambarkan dalam kurva fluktuasi perbandingan ${ }^{87} \mathrm{Sr} /{ }^{86} \mathrm{Sr}$ yang umumnya berlaku universal, antara lain kurva Mc Arthur (0-509 juta tahun), kurva Hodell (6,4-24 juta tahun) dan kurva Mobil (12-36 juta tahun). Diantara kurva perbandingan ${ }^{87} \mathrm{Sr} /{ }^{86} \mathrm{Sr}$, kurva Mc Arthur mencakup waktu geologi terpanjang (Gambar 3).

Penentuan umur batuan dengan metode SIS pada prinsipnya adalah dengan mem-plotkan harga perbandingan ${ }^{87} \mathrm{Sr} /{ }^{86} \mathrm{Sr}$ yang diperoleh dari pengukuran di laboratorium pada kurva-kurva tersebut diatas, sehingga diperoleh umur batuan yang diteliti. Lampiran 3 memperlihatkan perbandingan antara penampang 
stratigrafi berdasarkan indeks foraminifera besar dengan penampang stratigrafi berdasarkan ${ }^{87} \mathrm{Sr} /{ }^{86} \mathrm{Sr}$ ratio.

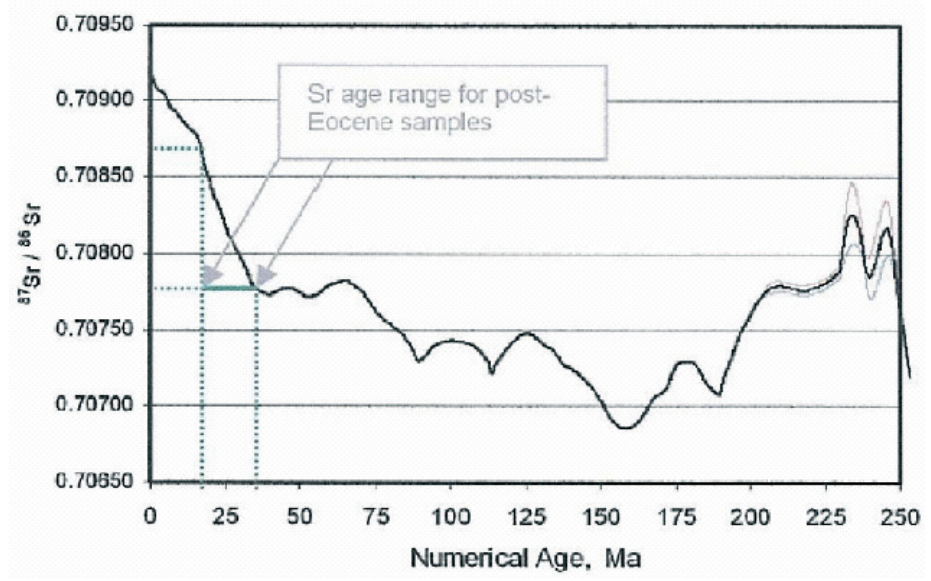

Gambar 3. Kurva Perbandingan ${ }^{87} \mathrm{Sr} /{ }^{86} \mathrm{Sr}$

\section{SEM dan XRD}

Untuk mendapatkan informasi tentang sifat fisik batuan, laboratorium eksplorasi LEMIGAS dilengkapi dengan peralatan berbasis teknologi nuklir seperti scanning electron microscope (SEM) dan X ray diffraction (XRD). SEM dimaksudkan untuk mengetahui porositas yang terbentuk dalam satu batuan, terutama yang diduga sebagai reservoir, yaitu berupa rongga primer maupun sekunder. Sementara itu, XRD memberikan data terkait jenis mineral penyusun batuan. Sebenarnya secara konvensional data tentang porositas dan jenis mineral penyusun batuan dapat ditentukan dengan menggunakan mikroskop polarisasi perbesaran $1000 \mathrm{kali}$, yang dikenal dengan analisis petrografi. Petrografi dilakukan terhadap sayatan tipis suatu perconto batuan (Gambar 4). Meskipun demikian, ahli sedimentologi merasa perlu untuk mengetahui segala hal terkait dengan kondisi fisik batuan secara lebih detil.

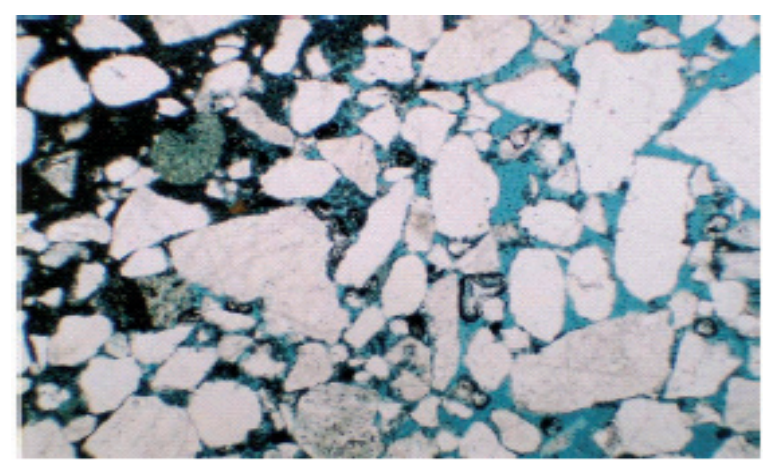

Gambar 4. Sayatan Tipis Batuan Untuk Analisis Petrografi 
Oleh karena itu kehadiran peralatan berbasis nuklir seperti SEM dan XRD sangat berguna karena mampu memberi informasi jauh lebih detil dari pada sekedar analisis mikroskopis. SEM sanggup memperbesar image puluhan ribu kali sehingga struktur dalam batuan terlihat dengan jelas termasuk porositas (Gambar 5). Sebaliknya metode XRD mampu memberi informasi tentang jenis mineral yang menyusun batuan sedimen berbutir halus seperti serpih dan lempung.

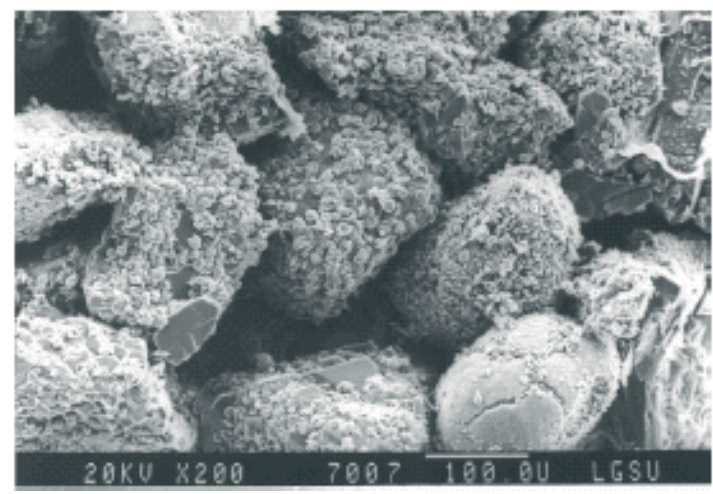

Gambar 5. Kondisi Geometri Pori Batuan Menggunakan SEM

Informasi ini sangat penting antara lain sebagai usaha pencegahan terhadap kemungkinan terjadi penjepitan pipa bor akibat menembus lapisan serpih atau lempung yang tersusun oleh mineral yang berdaya serap tinggi seperti . Gambar 6 memperlihatkan diagram yang menunjukkan komposisi mineral penyusun batuan sedimen hasil pengukuran menggunakan metode XRD.

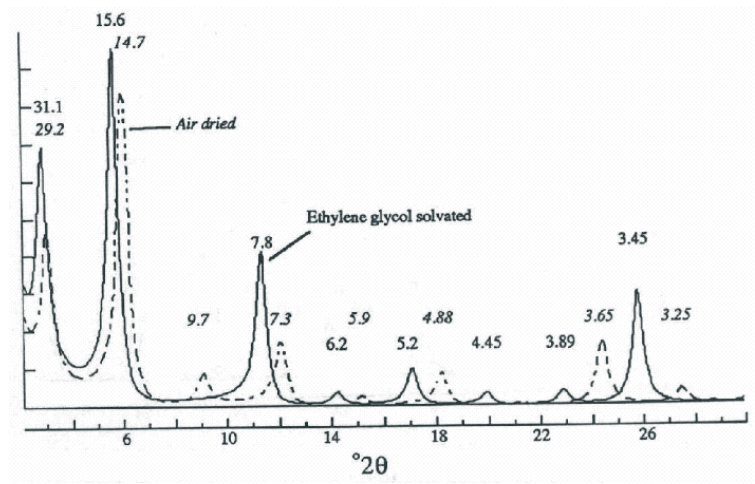

Gambar 6. Komposisi Mineral Dalam Batuan Berdasarkan XRD

Dengan demikian dapat disimpulkan bahwa jika dibandingkan dengan hanya menggunakan metode konvensional seperti petrografi, maka penggunaan peralatan berbasis iptek nuklir untuk menganalisis sifat fisik batuan termasuk SEM dan XRD memberikan nilai tambah dalam menunjang kegiatan eksplorasi migas. 


\section{NMR}

Nuclear Magnetic Resonance (NMR) adalah suatu alat menggunakan magnet untuk mempengaruhi dan mengukur momentum inti atom elemen tertentu. Istilah nuklir ditujukan pada inti atom dan resonansi magnetik adalah pengaruh magnet pada inti tersebut. Sehingga logging NMR berdasarkan atas gerakan inti atom hidrogen (proton) yang terdapat pada fluida (air dan hidrokarbon) dalam suatu lapisan. Inti atom mempunyai momentum magnetik sehingga dapat berputar (spinning) seperti batang magnet yang berputar (Gambar 7). Jika medan magnet diterapkan, inti ,magnetik cenderung untuk meluruskan diri dengan arah medan. Hal ini menghasilkan magnetisasi total atau polarisasi yang sebanding dengan besarnya medan magnet yang diberikan. Jika medan magnet tersebut diubah, harga keseimbangan baru dari polarisasi proton tidak stabil dan membutuhkan beberapa waktu untuk mencapai keseimbangan tergantung pada jumlah atom hidrogen yang tergantung dalam material. Proses untuk mendekati harga keseimbangan polarisasi disebut relaksasi.

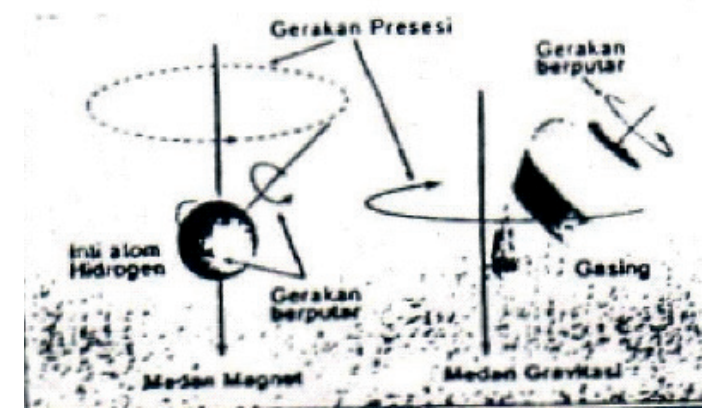

Gambar 7. Inti Atom Hidrogen Bertingkah Laku Seperti Batang Magnet Yang Berputar (Giroskop)

Parameter yang terukur adalah amplitudo sinyal dan waktu relaksasi sinyal. Amplitudo sinyal bergantung pada jumlah inti atom hidrogen yang ada pada batuan. Makin besar jumlah atom hidrogen, amplitudo makin besar. Waktu relaksasi bergantung pada ukuran pori-pori batuan. Pori-pori besar memberikan waktu relaksasi yang panjang dan mencerminkan banyaknya fluida yang terkandung pada suatu lapisan. Relaksasi dari komponen yang paralel dengan medan disebut relaksasi longitudinal dan ditandai dengan Tl. Relaksasi dari komponen yang tegak lurus disebut relaksasi transversal (T2) yang menggambarkan waktu yang dibutuhkan untuk relaksasi.

Ada 2 tipe alat NMR yang digunakan sekarang, yaitu MRIL (Magnetic Resonance Imager Log) yang dibuat oleh NUMAR Corp. dan CMR (Combinable Magnetic Resonance) yang dikembangkan oleh Schlumberger. Perbedaannya adalah sensor CMR ditempelkan pada dinding sumur selama pengukuran, sehingga tidak terpengaruh oleh salinitas lumpur pemboran. 
Alat logging NMR seperti ditunjukkan pada Gambar 8. Sensornya berbentuk skid yang terdiri dari 2 magnet permanen dan satu elemen yang berfungsi sebagai pemancar gelombang elektromagnetik frekuensi radio (RF) dan juga sebagai penerima sinyal (Gambar 9). Kedua magnet permanen menghasilkan medan magnet 1000 kali lebih kuat dari medan magnet bumf.

Ada 4 tahap pengukuran NMR (Gambar 10 a, b, c dan d):

1. Penjajaran proton (Gambar 10a); Magnet permanen menimbulkan medan magnet Bo yang digunakan untuk menjajarkan proton. Penjajaran memakan waktu beberapa detik dan akan tetap terjajarkan kecuali jika diganggu.

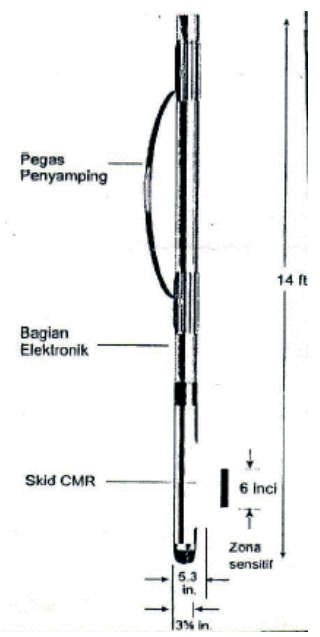

Gambar 8. Alat CMR, Panjangnya 14 Kaki Dan Dapat Disambung Dengan Log Lainnya.

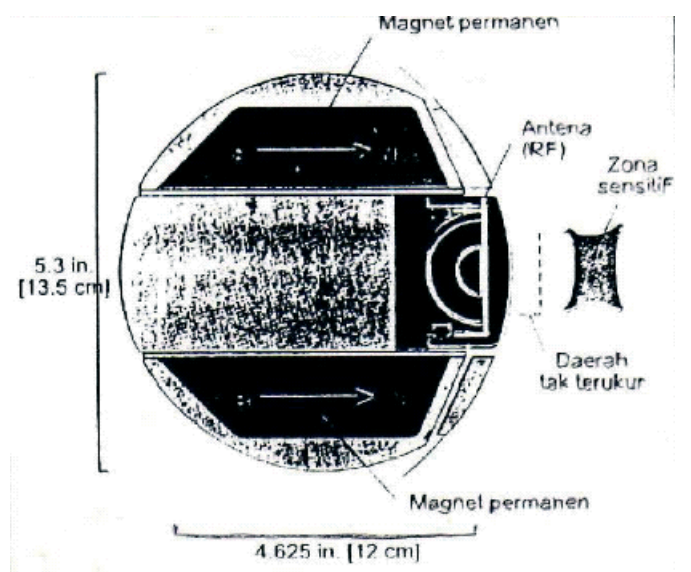

Gambar 9. Sensor CMR, Terdiri Dari Magnet Permanen Dan Antena Sebagai Pemancar dan Penerima. 
2. Perebahan spin (Gambar 10b)

Proton-proton yang telah dijajarkan, direbahkan dengan mengirimkan medan magnetik terisolasi Bo, yang tegak lurus dengan medan magnet Bo untuk waktu tertentu. Untuk perebahan diperlukan frekuensi seperti yang ditunjukkan pada Persamaan (1).

$$
f=g \text { Bo }
$$

dengan: $\mathrm{f}=$ frekuensi $\mathrm{B} 1$ atau frekuensi Larmor

$\mathrm{g}=$ tetapan giromagnetik ratio inti

3. Presisi dan defase (Gambar 10c)

Pada saat direbahkan $90^{\circ}$ dari arah Bo proton mengitari bidang yang tegak lurus terhadap Bo (berpresisi) dengan frekuensi yang berbeda, karena medan magnet Bo tidak homogen. Sehingga mereka kehilangan energi dan meluruh. Fase ini disebut defase dan waktu peluruhannya disebut $\mathrm{T} 2 *$.

4. Pemfokusan kembali (Gambar 10d)

Dilakukan dengan cara mengirimkan pulsa 180o yaitu sama dengan pulsa 90o tetapi 2 kali lebih lama. Proton akan berpresisi berbalik. Karena frekuensinya berbeda, proton akan kembali dengan kecepatan berbedabeda. Pulsa 180o dapat dilakukan berulang kali, biasanya beberapa ratus kali dalam satu pengukuran NMR. Seluruh urutan pulsa 90o dan 180o disebut urutan CPMG (Carr, Purcell, Meiboom dan Gill) untuk menghormati penemunya. Waktu peluruhan amplitudo disebut waktu relaksasi transversal (T2). Setelah beberapa waktu T2, proton akan kembali ke keadaan keseimbangannya sejajar terhadap Bo setelah urutan CPMG terjadi. Proses ini disebut relaksasi longitudinal (T1).

Log NMR mendapat sambutan yang baik dari para ahli sebagai alat petrofisika untuk evaluasi kualitas reservoar. Log NMR dapat digunakan untuk menentukan porositas; permeabilitas dan saturasi air irreducible.

Distribusi waktu relaksasi T2 berhubungan langsung dengan ukuran pori-pori. Rongga pori yang besar menghasilkan T2 yang lebih panjang, dan sebaliknya. Karena kecepatan relaksasi bergantung pada berapa sering proton dapat bertumbukan dengan permukaan butiran. Hal ini bergantung pada luas permukaan dan volume $(\mathrm{S} / \mathrm{V})$. Pori-pori besar (S/V kecil) tumbukan lebih jarang terjadi, dan sebaliknya, seperti pada Persamaan (2).

$$
1 / \mathrm{T} 2=\rho^{2}(\mathrm{~S} / \mathrm{V})
$$

dengan :

$\mathrm{T} 2=$ waktu relaksasi

$\mathrm{S}=$ luas permukaan butiran

$\mathrm{V}=$ volume batuan

$\rho=$ densitas 


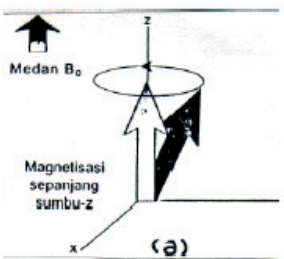

(a)

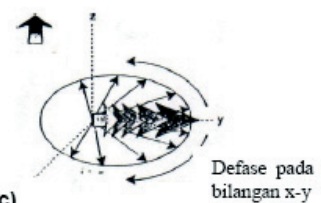

(c) bilangan $x-y$

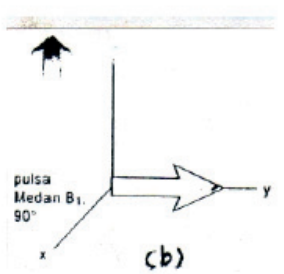

(b)

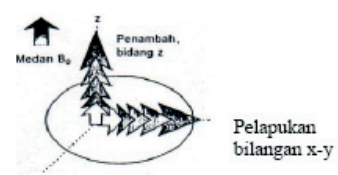

(d)

Gambar 10. Dasar pengukuran NMR. (a). Penjajaran proton. (b). Perebahan spin. (c). Presisi defase (d). Pemfokusan kembali

Jumlah pori yang ada pada batuan sama dengan volume fluida dari batuan tersebut, yaitu porositas. Log NMR mempunyai kemampuan untuk mengukur permeabilitas secara langsung di lapangan. Permeabilitas diturunkan dari hubungan empiris antara porositas NMR dan nilai rata-rata T2, seperti pada Persamaan (3).

$$
\mathrm{K} \text { NMR }=\mathrm{C}(\Phi \mathrm{NMR})^{4}(\mathrm{~T} 2,1 \mathrm{log})^{2}
$$

dengan :

KNMR $=$ permeabilitas

$\Phi_{\mathrm{NMR}}=$ porositas NMR

$\mathrm{T} 2, \log =$ rata-rata logaritmik dari $\mathrm{T} 2$

$\mathrm{C}=$ konstanta (4 untuk batu pasir dan 0,1 untuk karbonat)

Kelebihan lain dari log NMR adalah alatnya pendek dan ringan serta dapat dikombinasikan dengan alat log lain seperti resistivitas, densitas dan neutron. Contoh hasil rekaman dari log NMR diperlihatkan pada Gambar 11.

\section{KESIMPULAN}

Kegiatan eksplorasi migas di Indonesia telah dimulai sejak jaman prakemerdekaan Teknologi yang diterapkan pada masa itu relatif sederhana. Kini seiring dengan kemajuan iptek, metode eksplorasi migas berkembang pesat. Bahkan belakangan ini, kegiatan eksplorasi migas memanfaatkan kemajuan iptek nuklir seperti metode Strontium Isotope Stratigraphy (SIS), Scaning Electron Microscope (SEM), X Ray Diffraction (XRD) dan Nuclear Magnetic Resonance (NMR). Metode SIS digunakan untuk menghitung umur absolut suatu lapisan batuan, sedangkan metode SEM dipakai untuk melihat porositas batuan reservoir. XRD dimanfaatkan untuk 
menentukan jenis mineral penyusun batuan. NMR membantu ahli eksplorasi migas untuk menentukan porositas dan permiabilitas batuan serta keberadaan migas secara langsung.

Keterkaitan antara perkembangan iptek nuklir dengan perkembangan metode eksplorasi sangatlah erat. Di satu sisi kegiatan eksplorasi membutuhkan metodemetode baru untuk meningkatkan nilai keberhasilan dalam menemukan cadangan migas baru yang semakin lama semakin sulit karena kondisi geologinya yang semakin kompleks. Di sisi lain, perkembangan iptek nuklir diharapkan dapat memberikan kontribusi berupa penemuan-penemuan baru yang memberi nilai tambah dalam kegiatan eksplorasi migas. Peralatan berbasis iptek nuklir yang saat ini tersedia di pasaran dapat ditingkatkan mutunya, sehingga meningkatkan kepercayaan penggunanya terhadap teknologi ini.

\section{DAFTAR PUSTAKA}

1. BIL KENYON, KLEINBERG, R.,STRALEY,C., GUBELIN, G., MORRIS, C and A. HARSONO, 1966. ”NMR Teknologi Logging Abad ke 21”, JTMGB No. 5.

2. BROWN, R. J. S. and GAMSON, B. W., 1960. Nuclear Magnetism Logging. Society of Petroleum Engineers of AIME vol. 219.

3. DENISON, R. E., 1990. "Strontium Isotope Ages, Chemistry and Petrography of Samples from Lines 41 and 42", Papua New Guinea. GSPNG Unpublished Archive File F1/ R/ 91-47.

4. Herrick, R. C., Couturie, S. H. and Best, D. L., 1979. "An Improved Nuclear Magnetism Logging System and Its Application to Formation Evaluation”, Society of Petroleum Engineers of AIME 8361.

5. HODELl D. A., MUELlER, P. A. and GARRIDO J. R., 1991. Variations in the Strontium Isotopic Compositions of Seawater during Neogene. Geology 19, pp. 24-27.

6. MC ARTHUR J. M., HOWARTH R. J. and BAILEY, T. R., 2001. Strontium Isotope Stratigraphy: LOWESS Version 3: Best Fit to the Marine Sr-Isotope Curve for 0$509 \mathrm{Ma}$ and Accompanying Look-up Table for Deriving Numerical Age. Journal of Geology 109, pp. 155-170.

7. PAUL HULL and COOLIDGE, J. E., 1960. "Field Examples of Nuclear Magnetism Logging". Journal of Petroleun Technology.

8. ROBINSON, J. D., LOREN, J. D., VAJNAr, E. A. and HARTMAN, D. E., 1974. "Determining Residual Oil with the Nuclear Magnetism Log". Journal of Petroleun Technology. 


\section{Lampiran 1. Stratigrafi Umur Neogen}

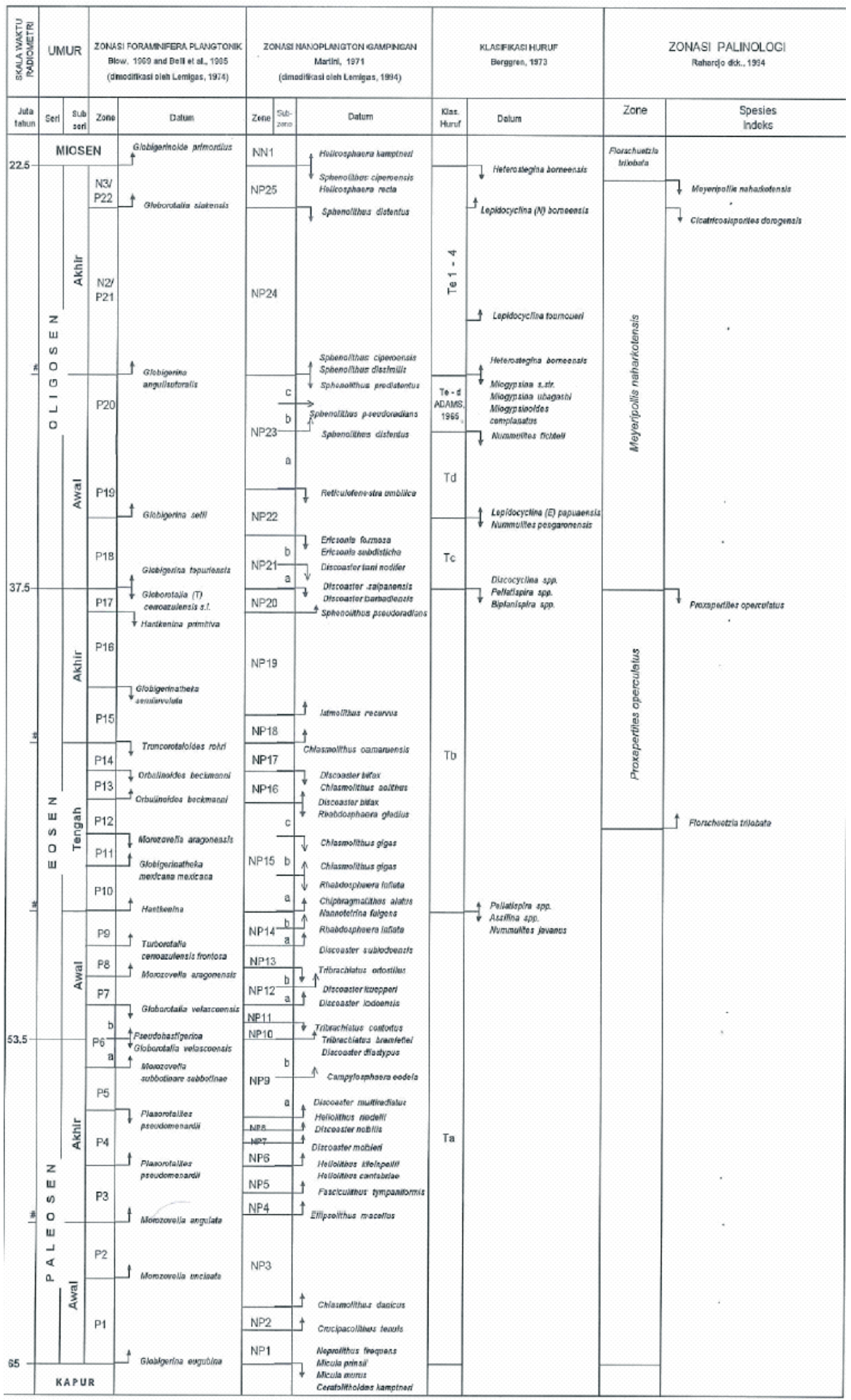


Lampiran 2. Kisaran Umur Foraminifera Besar

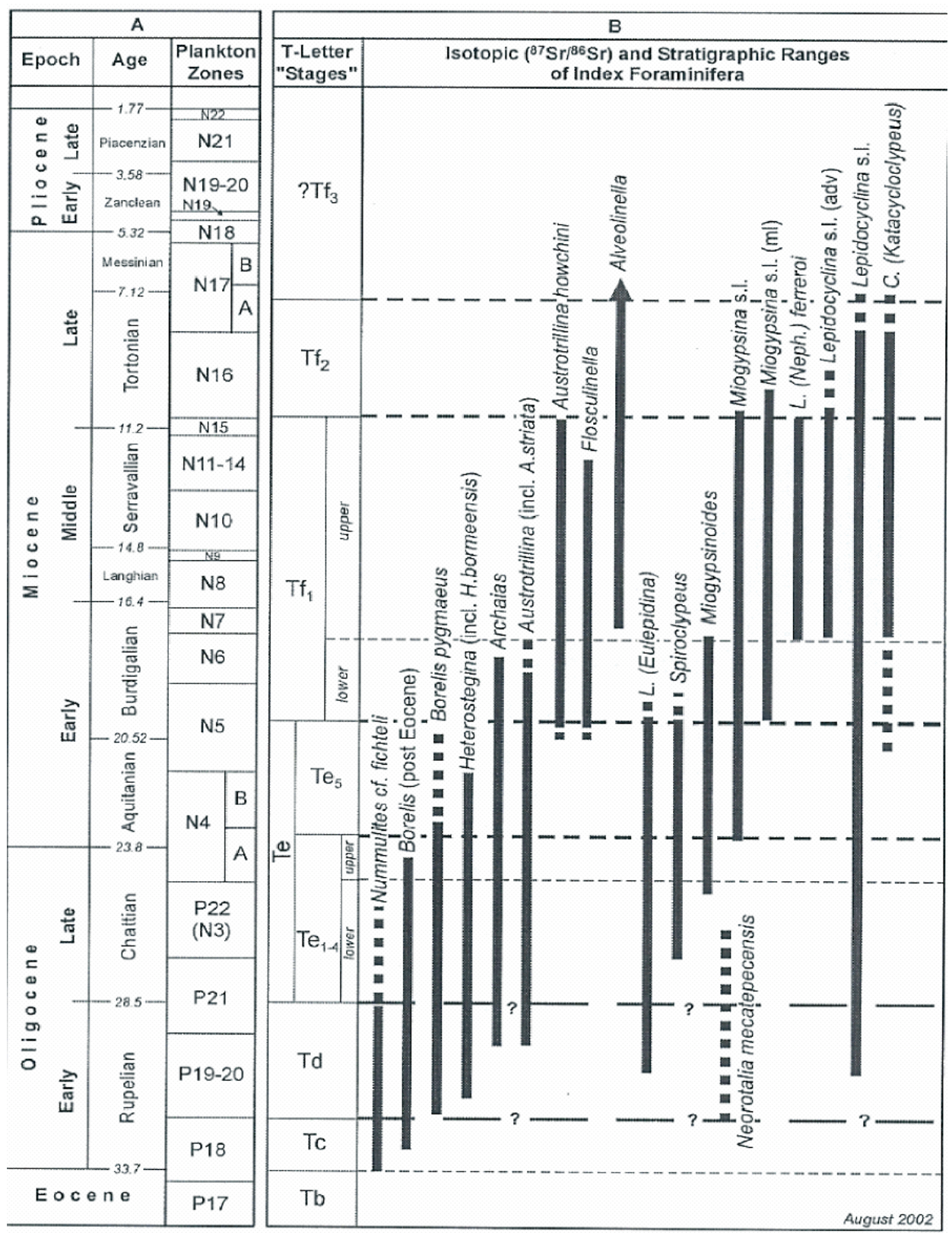


Lampiran 3. Penampang Stratigrafi Berdasarkan Umur Relatif Dan Absolut

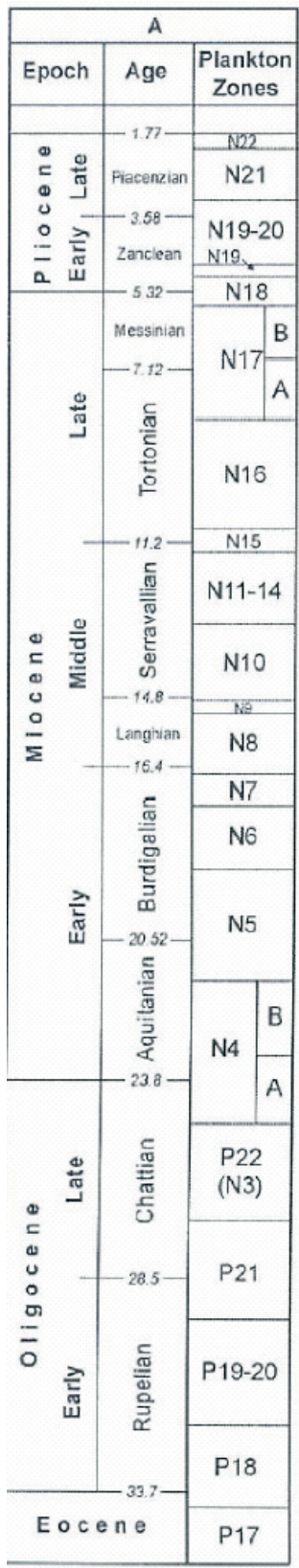
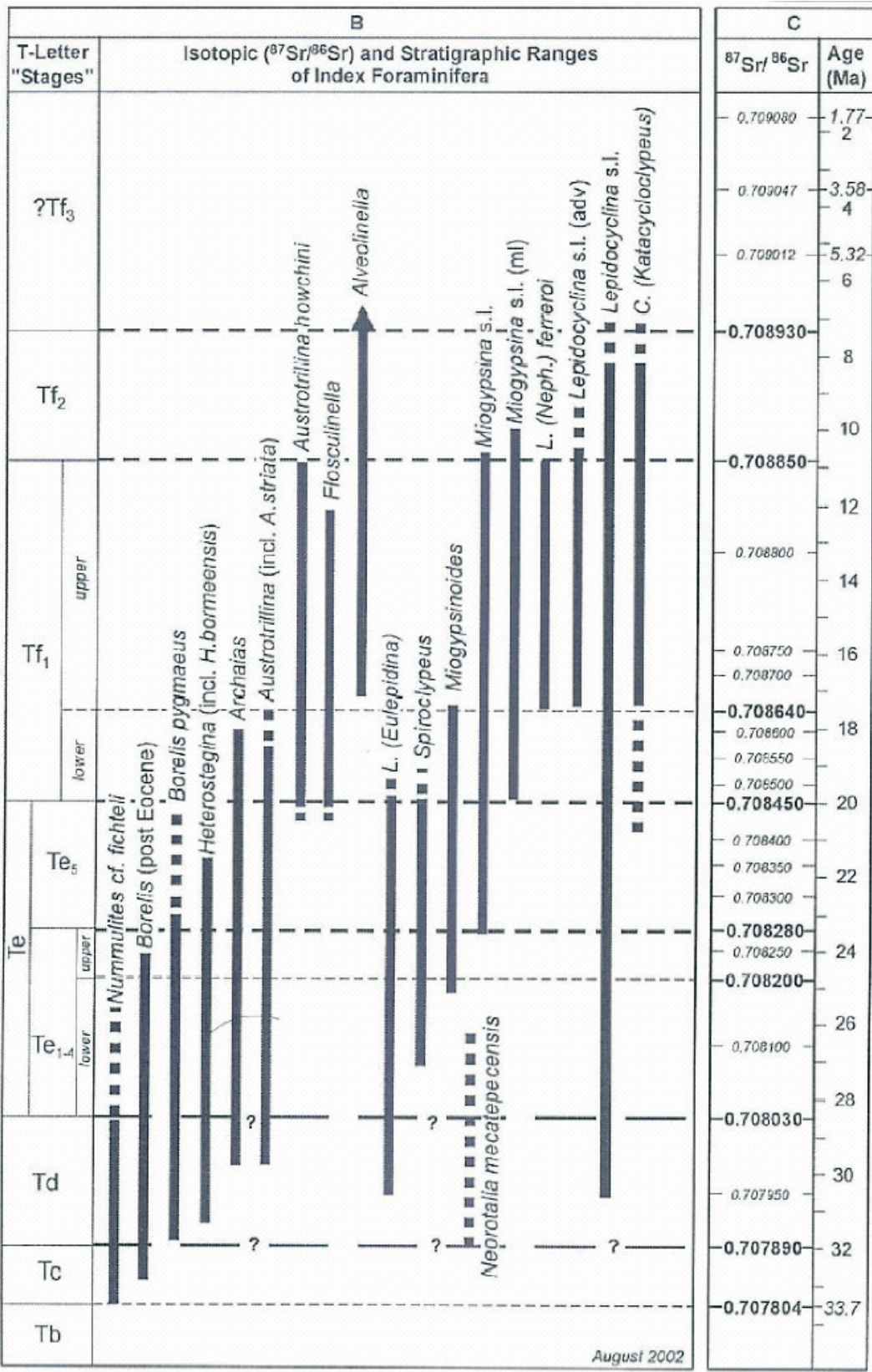